\title{
Domestic Violence and The Role of Women in Modern Minangkabau Society
}

\author{
Fatmariza $^{1}$, R Febriani $^{2}$ \\ $\left\{{ }^{1}\right.$ fatmariza@ fis.unp.ac.id, ${ }^{2}$ rika@lecturer.unp.ac.id $\}$ \\ ${ }^{1,2}$ Universitas Negeri Padang, Indonesia
}

\begin{abstract}
The level of domestic violence in West Sumatra is quite high. This is caused by various factors, including: economic, education, age and personality of the perpetrator. Even though the Minangkabau community in West Sumatra adheres to the matrilineal system and recognizes the role of women as limpapeh rumah nan gadang (respectable women), this does not guarantee low domestic violence in this region. One of the contributing factors is that there is still a strong patriarchal ideology in the society limited women to just taking care of the household and family. In practice, the role of ninik mamak as the highest decision maker tends to see that domestic violence becomes a shame for the family. Women are often blamed. Women in Minangkabau also tend to be reluctant to use legal channels to get justice because of such factor. How effective the role of adat in resolving domestic violence in West Sumatra? This paper will discuss the internalization of the local wisdom on the role of women and the issue of domestic violence in Minangkabau.
\end{abstract}

Keywords: Domestic Violence, Women, Adat, Mamak, Local Wisdom

\section{INTRODUCTION}

Domestic violence in West Sumatra is quite high if it's compared to other provinces in Indonesia. West Sumatra Local Police noted that in 2011 there were 299 cases, in 2012 there were 336 cases, and 350 cases in 2013. Another source from Center of Integrated Services for the Empowerment of Women and Children (P2TP2A) in 2016 stated that there were 64 cases of domestic violence [1]. Meanwhile, the latest data until June 2018, there were 56 cases [2]. Domestic violence is one of the highest causes of divorce among other causes. Several factors that cause the highest divorce are: continuous disputes, economic problems and one party leaves their partner [3].

The biggest reason is the absence of harmony in the household, namely $41 \%$ nationally. In most provinces includes sexual violence, where divorced plaintiffs (the wife) are reluctant to tell the reasons. This is because several factors; patriarchal culture, social pressure and the difficulty to proof in court. In certain provinces such as Aceh, West Sumatra, Riau, South Sumatra, Bengkulu, West Kalimantan, East Kalimantan, South Kalimantan and South Sulawesi, the reason for divorce is lack of harmony, where domestic violence is relatively striking compared to other categories [3].

The kind of domestic violence carried out by husbands include physical, psychological and economic violence from mild to severe. $59.8 \%$ of husbands had a history of past violence such 
as being beaten, thrown with goods, slapped, punched and kicked by their parents [4]. In line with this, $55.3 \%$ of husbands get poor parenting as a child and as many as $93 \%$ judge their parents often punish them for no apparent reason. There is a significant relationship between the history of past violence and parenting as a child. We can conclude that family factors can influence the formation of domestic violence behavior.

Culture is beliefs, practices, values, norms and actions shared by group members [5]. Cultural values and beliefs play an important role in shaping women's experiences of violence and their meaning for them. Women who experience domestic violence live in an environment that has a strong patriarchal tradition. Even though the role of women in the culture in Minangkabau is very important. Women as limpapeh rumah nan gadang have function as moral educators, the character of their children and are responsible for their families, tribes and people. Women also play a role as managers of household finances and inheritance key holder. Beside that women as determinants and men are implementers of public policy in Minangkabau [6], [7]. In the ethnography [8] women are seen as someone who gave birth to an heir to perpetuate the lineage. While the uncle from the mother's side manages the lineage and its members.

The cultural factors related to marriage and family honor have a significant impact on women in seeking help when domestic violence occurs. Marriage in the Minangkabau community and as Indonesian society in general is something sacred and must be maintained [9]. It is a disgrace to the family if a woman divorces her husband. So that the harsh treatment from the husband is hide and as far as possible not known by the public.

Adat is inseparable from Islam in Minangkabau. Both are seen as two pillars in one system; commitment to Islam is part of adat [7], [10]. Domestic violence in West Sumatra is inseparable from the interpretation of Islam towards women, [11] sees that the interpretation of gender bias towards Wadhribuhunna's sentence in surah Annisa's verse 34 is justification for men to commit domestic violence in Padang. The interpretation of the verses in the Qur'an is used as an excuse to conduct domestic violence where family settlement asks for opinions from religious leaders (mubaligh).

Settlement of domestic violence using customary law is not effective. This is due to the strong patriarchal views in the Minangkabau community. Though authority in the lineage or sub-lineage was in the hands of mamak (uncle of mother, not father). Mamak is responsible for carrying out, welfare and harmony within his saparuik region. So even though, women play an important role in perpetuating the lineage in Minangkabau society, but power is still in the hands of mamak. [12] sees that traditional leaders are mostly male elites who enjoy significant social and political power.

Women who experience domestic violence according to [13] have developed a coping strategy that moves like elastic rubber (tugging), which is to move actively against and surrender to the situation that they are facing. This strategy implies constant stretching by fighting violence through religious frameworks, seeking external support, being assertive and seeking positive diversions. But this stretch is often followed by withdrawing from society and giving up through obedience, remaining silent or ignoring husband's violent actions. Elastic rubber stretching is similar to how this woman struggled to improve her life by not being passive, but actively changing her life in her own way.

We find this kind of strategy done by Minangkabau women who experience domestic violence. Instead of telling their domestic violence experienced by their husband, they tend to handle it by themselves. Domestic violence issues are attempted to be resolved in a family manner first compared to bringing them to the court. Complaining about domestic violence issues to mamak is also not a way out. Mamak is now increasingly abandoned by its domestic scope. Mamak in his capacity is still notified of what happened to his nephew, things like: plans 
for education, work, and marriage remain a concern, but the implementation is still carried out by parents.

The power of mamak is expected to be able to settle domestic violence, but apparently not possible because domestic violence is considered as a family disgrace that must be covered up. Settlement of domestic violence takes precedence in the internal saparuik family. This indicates the importance of physical closeness for women to be in the same environment as their families. Is that effective in tackling domestic violence in the present day in the midst of modern Minangkabau society?

\section{RESEARCH METHOD}

This study used a qualitative method with compilation of domestic violence data in West Sumatra and compares the role of Minangkabau women in the society. Data on domestic violence in West Sumatra that used in this study came from: West Sumatra Local Police, Nurani Perempuan and Komnas Perempuan. With the use of data from these organizations it is hoped that research can focus on analyzing women's roles in Minangkabau. Qualitative research comes from Weber's sociology which emphasizes the development of understanding (Verstehen) and from Heidegger's phenomenology which emphasizes the importance of the everyday world (Lebeswelt) where we live and act [14].

This paper consists of four parts: first, introduction; second, research, methods; third, results and discussion and; fourth conclusions. This paper discusses how matrilineal culture can be sensitive to social problems in Minangkabau society. So it needs to be explored further about definitions and terminology that illustrate the importance of the role of women in the system of community and the facts that occur when there are cases of domestic violence.

\section{RESULT AND DISCUSSION}

Women in Minangkabau generally inherit agricultural land, houses, fish ponds (tabek), which are shared by their tribes. Heritage property especially immovable property is owned jointly and there is no private ownership in the structure of the Minangkabau community. Usage rights (ganggam bauntuak) are given to the saparuik family for the welfare of its members.

Meanwhile, the husband is urang sumando in his rumah gadang wife's. In principle, sumando is someone who is loaned by his tribe to his wife. In various ways, he is nothing more than a wife's brotherly relationship. In traditional Minangkabau society, husbands usually visit their wives at night and leave their homes in the morning [15]. When there is still a lot of land that is not cultivated, sumando usually works in the fields of his own rumah gadang, but because the population is increasing and the land is getting smaller, he can work on his land or his wife's house, depending on the availability of land.

But along with the times and high economic demands, most of these inheritance are no longer owned by women and sold by their heirs [16]. Even though the level of economic welfare of the people in the West Sumatra region is quite high, but the need for daily live is unavoidable by the poor. The fact is financial security is indirectly related to the ability of women to maintain their marriage when there is a domestic violence case occur.

The problems will arise if the husband (urang sumando) and the wife do not have land to cultivate, as is the case in many places in West Sumatra now. Women who are living in urban or rantau area such as: Padang no longer have inheritance. Apart from that, more and more women who live in rantau and work only to fulfill their daily needs. In areas that have a strong 
patriarchal tradition, such as: Pariaman, men remain in power even though they do not work. This can trigger domestic violence if the wife has a demands more than her husband's capacity.

To counteract domestic violence, the strong ties of families that living together can overcome this problem. Although it is no longer in the form of inheritance from rumah gadang, women who remain in their matrilineal relationship after marriage can prevent domestic violence. Households in Minangkabau are basically formed around women and their matrilineal networks. This could be derived from the ideology that rumah gadang is basically belongs to a family of women who still remain strong in the Minangkabau community.

Meanwhile, the culture of men sleeping in surau is not found any more in modern Minangkabau society. The difference between boys and girls is not very obvious. Boys can live in parent's homes and girls are allowed to go merantau. This shows matrilineal family ties become increasingly loose in modern Minangkabau society. The family ties are strangling and family responsibility is only centered on husband and wife relations .

Also, there is an ignorance from extended family exacerbated by the pattern of residence that has changed from the rumah gadang inhabited by many members of the extended family to a private house for the core family. The cultural shifts that are occurring in Minangkabau families distances family elders from younger members, and prevents their mediation in cases of domestic violence (Laeheem 2017). If a wife and the children still lived with the extended family in the rumah gadang, the instances of domestic violence would probably decrease.

\section{CONCLUSIONS}

Domestic violence in West Sumatra is remaining high because indirectly related to customs and culture that still patriarchal. Patriarchal culture sees that men have the right to punish women if they do not comply with their wishes and not accordance with the teachings of Islam. Meanwhile, it cannot be denied that material problems become one of the factors that trigger domestic violence in modern Minangkabau families. The absence of the availability of land to be worked on by the husband (urang sumando) makes the burden increasingly heavy for families living in urban areas such as Padang and rantau. This paper concludes that domestic violence can be prevented if women live close to their matrilineal family due to the existence of social control that still maintains the role of women as a limpapeh rumah nan gadang, even though it is no longer in the traditional kinship system. Adat system has a strong influence on the resilience of households to the extent that the family still maintains a strong traditional tradition.

\section{REFERENCES}

[1] I. Wahyudi, "P2TP2A Terima Laporan 64 Kasus Kekerasan Perempuan," 2016. .

[2] P. S. Unit for Women and Children Services, Laporan Kekerasan Dalam Rumah Tangga Provinsi Sumatera Barat. 2018.

[3] et al Adriana Venny, "Tergerusnya Ruang Aman Perempuan Dalam Pusaran Politik Populisme," Komnas Perempuan, no. 1, pp. 430-439, 2018.

[4] M. Ramadani and F. Yuliani, "Kekerasan Dalam Rumah Tangga (Kdrt) Sebagai Salah Satu Isu Kesehatan Masyarakat Secara Global,” Jurnal Kesehatan Masyarakat Andalas, vol. 9, no. 2, p. 80, 2017.

[5] Jenny C.Tonsing, "Domestic Violence: Intersection of Culture, Gender and Context," $J$ Immigrant Minority Health, vol. 18, pp. 442-446, 2016.

[6] K. Audrey, Dari Pemberontakan ke Integrasi, Sumatra Barat dan Politik Indonesia 
1926-1998. Yayasan Obor Indonesia, 2005.

[7] A. A. Navis, Alam Takambang Jadi Guru: Adat Dan Kebudayaan Minangkabau. Jakarta: Grafiti Press, 1984.

[8] T. Kato, "Change and Continuity in the Minangkabau Matrilineal System," Indonesia, vol. 25, no. 25, pp. 1-16, 1978.

[9] A. Asmaniar, "Perkawinan Adat Minangkabau," Binamulia Hukum, vol. 7, no. 2, pp. 131-140, 2018.

[10] T. Abdullah, "Adat and Islam: An Examination of Conflict in Minangkabau," Indonesia, vol. 2, p. 1, Oct. 2006.

[11] Fatmariza, "Fenomena Kekerasan Terhadap Perempuan Di Dalam Rumah Tangga (Pandangan Mubalig)," Humanus, vol. XI, pp. 172-180, 2012.

[12] J. Bond, "Gender, Discourse, and Customary Law in Africa," 83 S. CAL. L. REV, pp. 511-512, 2010.

[13] Elli Nur Hayati, "Domestic Violence Against Women in Rural Indonesia, Searching for Multilevel Prevention," Umea University, 2013.

[14] J. Smith, "Quantitative versus qualitative research: An attempt to clarify the issue," Educational Researcher, vol. 2, no. 3, pp. 6-13, 1983.

[15] De Josselin de Jong, Minangkabau and Negri Sembilan. Den Haag: Martinus Nijhoff, 1980.

[16] K. Saddhono, "Language of Coastal Communities in the Northern Coast of Central Java: Sociolinguistic Studies in Cultural Integration Maritime-Agrarian Perspective." Adv. Sci. Let. vol. 23 no. 10 pp 10054-10056, 2017 